Diseases (Scotland) Unit was set up in 1977, and in that year detected 15 infections. The numbers doubled each subsequent year, ${ }^{3}$ and in 1982 reached 1033 reported infections (table II), including 519 indigenous infections (half of the total) in which the consort was also infected in Britain: 154 of these indigenous infections were contracted in Greater London, 30 in Birmingham, 28 in Liverpool, 20 in Bristol, 18 in Leeds, and fewer cases in other areas. ${ }^{4}$

TABLE II-Number (\%) of gonococcal infections with $\beta$ lactamase producing Neisseria gonorrhoeae, 1977-82, United Kingdom

\begin{tabular}{lcccccc}
\hline Place of infection & 1977 & 1978 & 1979 & 1980 & 1981 & 1982 \\
\hline Outside UK & $7(47)$ & $18(58)$ & $55(53)$ & $110(52)$ & $168(38)$ & $237(23)$ \\
UK consort overseas & $1(7)$ & $3(10)$ & $13(13)$ & $21(10)$ & $46(10)$ & $65(6)$ \\
UK consort in UK & $5(33)$ & $8(26)$ & $21(20)$ & $50(24)$ & $165(37)$ & $519(50)$ \\
Not known & $2(13)$ & $2(6)$ & $15(14)$ & $30(14)$ & $64(14)$ & $212(21)$ \\
\hline Total & 15 & 31 & 104 & 211 & 433 & 1033 \\
\hline
\end{tabular}

The infection has now become endemic in several cities, particularly London; control measures appear to have been ineffective. Spectinomycin resistant strains of $\beta$ lactamase producing $N$ gonorrhoeae were reported in California in April 1981 and in London in November 1981; in 1982 there were four further reports from London clinics (spectinomycin resistant $\beta$ lactamase producing Neisseria gonorrhoeae: CDR 82/37, unpublished).

\section{Acquired immune deficiency syndrome}

In 1981 an outbreak of Pneumocystis carinii pneumonia was reported in the United States in homosexual men, ${ }^{5}$ and at about the same time Kaposi's sarcoma was described, also in homosexual men. ${ }^{6}$ The apparently new disease, the full definition of which is available from the Communicable Disease Surveillance Centre, became known as AIDS. Seven cases were diagnosed in the United States in 1979, 43 in 1980, 215 in 1981, and 750 in 1982 , with a mortality of at least $50 \%$. Most of the cases were in homosexual men but other groups mentioned included intravenous drug abusers, immigrants from Haiti, and haemophiliacs.

In 1982 a surveillance system was set up in Britain to detect the syndrome and to monitor trends. The system comprises, firstly, clinical reports of suspected cases to the Communicable Disease Surveillance Centre and Communicable Diseases (Scotland) Unit from venereologists and other clinicians; secondly, laboratory reports of opportunistic infections; and, thirdly, death certificates mentioning Kaposi's sarcoma or AIDS, provided by the Office of Population, Censuses, and Surveys.?

Fifteen cases meeting the criteria of the Centers for Disease Control definition of AIDS, 11 of which were fatal, were reported to the Communicable Disease Surveillance Centre up to 31 December 1983 with dates of onset of symptoms in 1982 or before ( 11 of them in 1982 and four with earlier onsets). Fourteen were white men and one an African woman from Zambia who had travelled in Central Africa and came to England in 1981, subsequently developing a fatal cerebral toxoplasmosis. Eleven of the men were homosexual, one of whom was a drug abuser; none of them was known to have received blood or blood products; nine of these 11 died, six with pneumocystis pneumonia and two with Kaposi's sarcoma, and one with other opportunistic infections. There were three heterosexual men: two had received American factor VIII concentrate for the treatment of haemophilia and one of these died (table III). Five of the 11 homosexual patients gave a history of contact with United States nationals; in six the social history was not known; there were no cases investigated in which an association with United States nationals could be definitely excluded.

The syndrome is considered likely to be due to an agent, transmissible mainly in blood and blood products, which is spread
TABLE III-Acquired immune deficiency syndrome. Cases with onset of symptoms during or before $1982^{*}$ in United Kingdom. Number of deaths given in parentheses

\begin{tabular}{lcccc}
\hline Risk factor & $\begin{array}{c}P \text { carinii } \\
\text { pneumonia }\end{array}$ & $\cdot \begin{array}{c}\text { Kaposi's } \\
\text { sarcoma }\end{array}$ & $\begin{array}{c}\text { Other } \\
\text { opportunistic } \\
\text { infections }\end{array}$ & Total \\
\hline $\begin{array}{l}\text { Homosexual associated with } \\
\text { North America }\end{array}$ & $2 \dagger(2)$ & $2(2)$ & $1(1)$ & $5(5)$ \\
$\begin{array}{l}\text { Homosexual, no social history } \\
\text { available }\end{array}$ & $4(4)$ & 1 & 1 & $6(4)$ \\
$\begin{array}{l}\text { Heterosexual } \\
\text { Haemophiliac } \\
\text { African women }\end{array}$ & 0 & 1 & 0 & 1 \\
\hline \multicolumn{1}{c}{ Total } & $1(1)$ & 0 & 1 & $2(1)$ \\
& $7(7)$ & $4(2)$ & $4(2)$ & $15(11)$ \\
\hline
\end{tabular}

*Reported up until 31 December 1983.

+1 case was also an intravenous drug user.

sexually, parenterally, or perinatally. ${ }^{8}$ Most of the patients in the United Kingdom in and before 1982 has associations with North America (five homosexuals, two haemophiliacs, and one heterosexual) and this would appear to be an important risk factor. Possibly, however, this association with North America was spurious and due to increased overseas travel, but the decline in syphilis in men, especially that acquired abroad, suggests that this was not so. A case control study is planned to define more clearly the risk factors in Britain.

\section{References}

${ }^{1}$ British Cooperative Clinical Group. Homosexuality and venereal disease in the United Kingdom: a second study. Br 7 Vener Dis $1980 ; 56: 6-11$.

Percival A, Corkhill JE, Arya OP, et al. Penicillinase-producing gonococci in Liverpool. Lancet 1976; ;i: 1379-82.

${ }^{3}$ McCutchan JA, Adler MW, Berrie JRH. Penicillinase-producing Neisseria gonorrhoeae in Great Britain, 1977-81 : alarming increase in incidence and recent development of endemic transmission. $\mathrm{Br}$ Med f 1982;285:337-40.

Public Health Laboratory Service Communicable Disease Surveillance Centre and the Communicable Diseases (Scotland) Unit. Penicillinase-producing Neisseria gonorrhoeae in Britain 1982. Br Med F 1983;286:1628-9.

$1981 ; 30: 250-2$.

Centers for Disease Control. Kaposi's sarcoma and Pneumocyst is pneumonia among homosexual men-New York City and California. MMWR 1981;30:305-8.

Public Health Laboratory Service Communicable Disease Surveillance Centre. Surveillance of the acquired immune deficiency syndrome in the United Kingdom, January 1982-July 1983. Br Med $₹$ 1983;287:407-8

${ }^{8}$ Waterson AP. Acquired immune deficiency syndrome. Br Med $尹$ 1983;286:743-6.

A 10 month old boy has been living in the Netherlands where he had his routine immunisations. Their regimen differs from that in the United Kingdom in that diphtheria, tetanus, pertussis, and polio, are all given by injection at 4, 5, 7, and 11 months. Should I give this boy another injection or may I omit it without affecting the extent of his protection?

The timing of the Dutch schedule will have been assessed by population studies. These will have shown that a certain proportion, probably small, of those studied will have required a fourth dose to become adequately protected, especially with the relatively short interval between the first three doses. So I would immunise him again against diphtheria, tetanus, and poliomyelitis (oral poliomyelitis vaccine may be substituted for inactivated vaccine) to be certain of protection until the next booster at school entry on the United Kingdom schedule. Whether the pertussis component should be again boosted in this boy when he is leaving the most dangerous age for contracting pertussis is debatable. A fourth dose is not recommended by the Joint Committee on Vaccination and Immunisation, even when the normal scheduled intervals are shortened to one month during epidemics. I would withhold this component, particularly if there is any parental doubt.-G R WILLIAMS, lecturer in infectious diseases, Glasgow.

\section{Correction}

\section{ABC of Asthma: Asthma in children: treatment}

We regret that an error occurred in this article by Dr John Price (23 June, p 1895). The comic "The Winner" shown in the second illustration has been produced by a group of Scottish doctors and is not distributed by Sandoz. It is not yet widely distributed, and inquiries should be addressed to Dr Roland Clark, King's Cross Hospital, Dundee. 